\title{
Significance of Pyrolytic Temperature, Particle Size, and Application Rate of Biochar in Improving Hydro-Physical Properties of Calcareous Sandy Soil
}

\author{
Abdulaziz G. Alghamdi ${ }^{1, *}{ }^{-}$, Abdulrasoul Al-Omran ${ }^{1}\left(\mathbb{D}\right.$, Arafat Alkhasha ${ }^{1}$, Zafer Alasmary ${ }^{1}$ and \\ Anwar A. Aly 2 (D) \\ 1 Soil Sciences Department, College of Food and Agricultural Sciences, King Saud University, P.O. Box 2460, \\ Riyadh 11451, Saudi Arabia; rasoul@ksu.edu.sa (A.A.-O.); aalkhasha@ksu.edu.sa (A.A.); \\ zalasmari@ksu.edu.sa (Z.A.) \\ 2 Soil and Water Science Department, Faculty of Agriculture, Alexandria University, Alexandria 21545, Egypt; \\ aaaly@alexu.edu.eg \\ * Correspondence: agghamdi@ksu.edu.sa; Tel.: +966-56298-5495
}

check for updates

Citation: Alghamdi, A.G.; Al-Omran, A.; Alkhasha, A.; Alasmary, Z.; Aly, A.A. Significance of Pyrolytic Temperature, Particle Size, and Application Rate of Biochar in Improving Hydro-Physical Properties of Calcareous Sandy Soil. Agriculture 2021, 11, 1293. https://doi.org/ 10.3390 /agriculture 11121293

Academic Editor: Mumtaz Cheema

Received: 27 October 2021

Accepted: 17 December 2021

Published: 19 December 2021

Publisher's Note: MDPI stays neutral with regard to jurisdictional claims in published maps and institutional affiliations.

Copyright: (C) 2021 by the authors Licensee MDPI, Basel, Switzerland. This article is an open access article distributed under the terms and conditions of the Creative Commons Attribution (CC BY) license (https:/ / creativecommons.org/licenses/by/ $4.0 /)$.

\begin{abstract}
Water management and irrigation conservation in calcareous sandy soil are of significant importance for sustaining agricultural production, especially in arid and semi-arid region that facing scarcity of water resources. The changes in hydro-physical characteristics of calcareous sand soil were investigated after date palm waste-derived biochar application in column trials. Significance of pyrolysis temperature $\left(300{ }^{\circ} \mathrm{C}, 500{ }^{\circ} \mathrm{C}\right.$, and $\left.700{ }^{\circ} \mathrm{C}\right)$, particle size $\left[<0.5 \mathrm{~mm}\left(\mathrm{D}_{0.5}\right), 0.5-1 \mathrm{~mm}\left(\mathrm{D}_{1}\right)\right.$, and $\left.1-2 \mathrm{~mm}\left(\mathrm{D}_{2}\right)\right]$, and application rate $(1 \%, 2.5 \%$, and $5 \%)$ were studied. Variations in infiltration rate, intermittent evaporation, and saturated hydraulic conductivity as a function of aforementioned factors were investigated. After amending the top $10-\mathrm{cm}$ soil layer with different biochar and application rates, the columns were subjected to six wetting and drying cycles by applying $25 \mathrm{~cm}^{3}$ tap water per week over a 6-week period. Overall, biochar application resulted in decreased saturated hydraulic conductivity, while improved cumulative evaporation. Specifically, biochar produced at $300{ }^{\circ} \mathrm{C}$ and $500{ }^{\circ} \mathrm{C}$ demonstrated $10.2 \%$ and $13.3 \%$ higher cumulative evaporation, respectively., whereas, biochar produced at $700{ }^{\circ} \mathrm{C}$ with $5 \%$ application rate resulted in decreased cumulative evaporation. Cumulative evaporation increased by $5.0 \%, 7.7 \%$ and, $7.8 \%$ for $\mathrm{D}_{0.5}, \mathrm{D}_{1}$ and $\mathrm{D}_{2}(\mathrm{~mm})$ on average, respectively, as compared with the untreated soil. Thus, biochar with particle size $0.5-1 \mathrm{~mm}$ significantly improved hydro-physical properties when applied at 1\%. Generally, using biochar produced at medium temperature and small particle size with appropriate application rates could improve the soil hydro-physical properties.
\end{abstract}

Keywords: date palm biochar; hydro-physical properties; intermittent evaporation; water retention; hydraulic conductivity; cumulative infiltration

\section{Introduction}

Soil physical properties are important factors that impact crop production and water use in the root zone, especially in arid and semiarid regions, which are characterized by high temperatures, low rainfall, and sandy soils. Scientists seek to find amendments that can improve the hydraulic properties of these soils to increase agricultural production, such as lowering infiltration rate, reducing evaporation, decreasing hydraulic conductivity, increasing available water, and reducing bulk density. Application of amendments is considered as a means to enhance soil physical properties and hydrological parameters. Amendments such as polymers, organic matter, and clay deposits have been widely used in Saudi Arabia to improve soil hydraulic properties, irrigation water conservation and thus, sustain crop production [1-3]. Recently, biochar produced from carbonization of tree wastes has been used to alleviate undesirable soil chemical and physical properties [4]. 
Studies have shown that biochar from different feedstock materials, applied to fields for a long time, could enhanced the hydro-physical properties of soil, because it increases macro- aggregates and aggregate stability and improves water retention capacity. It also enhances available water content and allows for the formation of new pores by modifying the arrangement of soil particles [5]. Saffari et al. [6] repotted that soil water retention, penetration resistance, bulk density, and total porosity were increased by biochar application. Furthermore, Hussain et al. [7] showed that the application of biochar to soil enhanced soil water retention characteristics (SWRC), like $\theta r$ (residual water content), the air entry value, and the water content. These results were due to the properties of biochar, such as high specific surface area (SSA) and the presence of functional groups that can absorb nutrients. Razzaghi et al. [8] found that biochar decreased bulk density by $9 \%$, while it increased water retention at field capacity (FC) and the wilting point (WP). Plant available water content (AW) was also increased by $14 \%, 21 \%$, and $45 \%$ for fine, medium, and coarse textured soil, respectively. Biochar improved bulk density, porosity, moisture content, mean weight diameter of soil aggregates, dispersion ratio, and infiltration rate [9]. The particle size of biochar is an important factor that can enhance water holding capacity and bulk density [10]. In a study with biochar, Glab et al. [11] applied two different types and three different sizes $(0-0.5,0.5-1$ and $1-2 \mathrm{~mm})$, applied at four different rates $(0.5 \%, 1 \%, 2 \%$ and $4 \%)$. They found that the small particles of biochar increased available water content.

With respect to the influence of pyrolytic temperature, most studies have focused on chemical properties of soil. For example, Usman et al. [12] reported that, with increasing pyrolytic temperature, fixed $\mathrm{C}$, ash, and basic cations of date palm biochar increased while moisture, volatiles, and elemental composition $(\mathrm{O}, \mathrm{H}, \mathrm{N}$, and $\mathrm{S})$ decreased. Surface basicity of biochar increases with increasing pyrolytic temperature, and, consequently, $\mathrm{pH}$ increases. Increasing the pyrolytic temperature results in volatilizing some elements such as $\mathrm{N}$ and $\mathrm{S}$, but it can cause other elements such as $\mathrm{C}$ to concentrate in the biochar, Bridle and Pritchard [13]. The pyrolytic temperature has a direct influence on the elements in the feedstock, and they may be lost to the atmosphere, fixed into more stable fractions, or released as soluble forms during the pyrolytic process [14,15].

In Saudi Arabia date palms are widely grown. Currently, the number of cultivated date palm trees has reached 32 million trees and the production is estimated to be $1,539,775$ tons [16]. Date palm cultivation is producing tons of wastes that can be utilized on farms. Few studies have investigated the effect of date palm waste on hydrophysical properties of calcareous sandy soil. Therefore, the objective of this study was to evaluate the physical characteristics of a loamy sand in Saudi Arabia as influenced by the addition of date palm biochar produced at different pyrolytic temperatures and with different particle sizes.

\section{Materials and Methods}

2.1. Experimental Design

2.1.1. Preparation of Soil Sample

Soil was brought from an area with a private agricultural project located in the Thadeq Governorate in central Saudi Arabia $\left(25^{\circ} 17^{\prime} 40^{\prime \prime} \mathrm{N}\right.$, and $45^{\circ} 52^{\prime} 55^{\prime \prime}$ E). Figure 1 shows the geographical map of the sampling sites. Soil samples were collected from one site at the surface soil layer $(0-30 \mathrm{~cm})$ and brought to the laboratory. Soil was air-dried and sieved through a 2-mm sieve for analysis. Soil texture was determined by the hydrometer method [17]. Soil $\mathrm{pH}$ was measured using a digital $\mathrm{pH}$ meter (WTW $\mathrm{pH} 315 \mathrm{i}$, Weilheim, Germany) in a saturated soil paste [18]. The electrical conductivity (EC) was measured in a saturated paste extract using a digital EC meter (Jenway 4510 conductivity meter, Stone, Staffordshire, UK). Calcium carbonate was determined using a Calcimeter (Eijkelkamp, Agriearch Equipment, Giesbeek, the Netherlands). Soil organic matter was measured according to [18]. The physio-chemical characteristics of soil are presented in Table 1. 


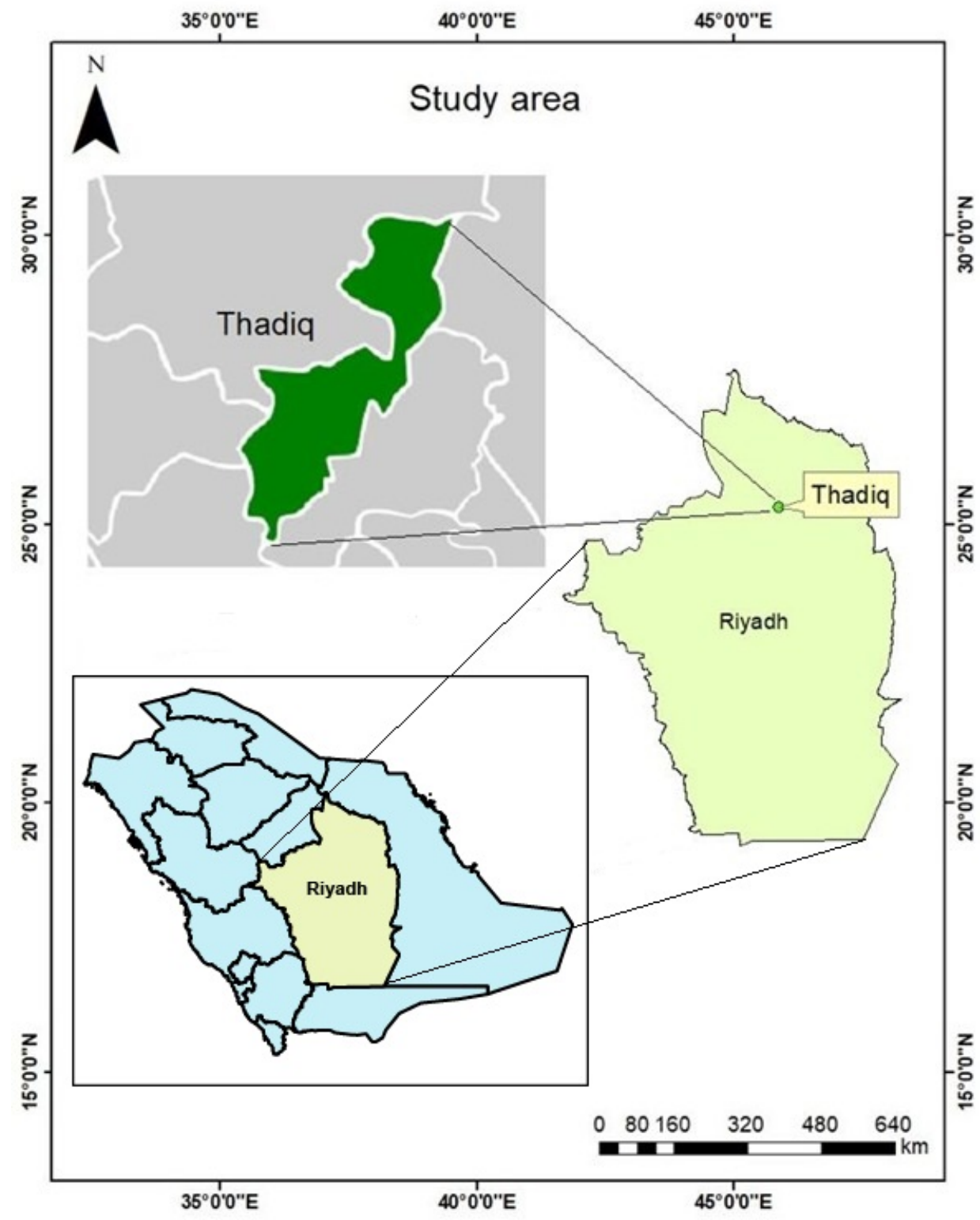

Figure 1. Geographical map of the sample site.

Table 1. Chemical and physical properties of the soil.

\begin{tabular}{|c|c|c|c|c|c|c|c|c|c|c|}
\hline \multicolumn{11}{|c|}{ Physical Properties } \\
\hline Sand $(\%)$ & Silt $(\%)$ & Clay (\%) & \multicolumn{2}{|c|}{ Soil Texture } & \multicolumn{2}{|c|}{ Bulk density $\left(\mathrm{g} \mathrm{cm}^{-3}\right)$} & $\mathrm{CaCO}_{3}(\%)$ & \multicolumn{2}{|c|}{$\mathrm{Ks}\left(\mathrm{cm} \mathrm{day}^{-1}\right)$} & WHC (\%) \\
\hline 88.1 & 2.0 & 9.9 & \multicolumn{2}{|c|}{ Loamy sand } & \multicolumn{2}{|c|}{1.53} & 13.4 & \multicolumn{2}{|c|}{121.37} & $25-27$ \\
\hline \multicolumn{11}{|c|}{ Chemical properties of soil and water. } \\
\hline \multirow{2}{*}{ Types of sample } & \multirow{2}{*}{$\mathrm{pH}$} & \multicolumn{5}{|c|}{ Cations (meq $\mathrm{L}^{-1}$ ) } & \multicolumn{4}{|c|}{ Anions (meq $\mathrm{L}^{-1}$ ) } \\
\hline & & $\begin{array}{c}\text { E.C dS m }{ }^{-1} \\
2.39\end{array}$ & $\begin{array}{l}\mathrm{Ca}^{+2} \\
10.92\end{array}$ & $\begin{array}{c}\mathrm{Mg}^{+2} \\
2.25\end{array}$ & $\begin{array}{l}\mathrm{Na}^{+} \\
6.58\end{array}$ & $\begin{array}{c}\mathrm{K}^{+} \\
5.10\end{array}$ & $\begin{array}{l}\mathrm{Cl}^{-} \\
2.50\end{array}$ & $\begin{array}{c}\mathrm{HCO}_{3}^{-} \\
0.83\end{array}$ & $\begin{array}{c}\mathrm{SO}_{4}{ }^{-2} \\
19.83\end{array}$ & $\begin{array}{l}\text { SAR } \\
2.56\end{array}$ \\
\hline Water applied to columns & 7.67 & 1.4 & 5.6 & 5.4 & 3.39 & 0.64 & 11 & 2.4 & 1.63 & 4.02 \\
\hline
\end{tabular}

Ks = hydraulic conductivity, WHC = water holding capacity, SAR = Sodium adsorption ratio.

\subsubsection{Biochar Preparation}

Biochar derived from date palm residues, such as fronds and rachis, were exposed to direct sunlight to dry out and then cut in to small pieces $(5-10 \mathrm{~cm})$. The date palm pieces were packed tightly in a stainless-steel cylinder (50 $\mathrm{cm}$ radius and $80 \mathrm{~cm}$ length) to minimize air volume and to provide nearly oxygen-free conditions. The date palm pieces 
were put into an oven and were subjected to pyrolysis at three different temperatures: $300{ }^{\circ} \mathrm{C}, 500{ }^{\circ} \mathrm{C}$, and $700{ }^{\circ} \mathrm{C}$ for $3 \mathrm{~h}$, which were designated as $\mathrm{T}_{300}, \mathrm{~T}_{500}$, and $\mathrm{T}_{700}$. Then the biochar was ground and divided by a mechanical sieve into three parts according to the following order less than $0.5,0.5-1.0$, and $1-2 \mathrm{~mm}$, which were designated as $\mathrm{D}_{0.5}, \mathrm{D}_{1}$, and $\mathrm{D}_{2}$, respectively. The $\mathrm{pH}$ of the biochar was measured in a suspension of biochar-to-water ratio of 1:10, and also the EC was measured in 1:10 extract of biochar-to-water [19].

\subsubsection{Soil Columns Preparations}

Soil columns were made of transparent plastic, and the bottoms were closed off using filter paper and gauze fabric. The columns were $45 \mathrm{~mm}$ in internal diameter and $400 \mathrm{~mm}$ in height. The control column was packed to the $30-\mathrm{cm}$ depth with $763.02 \mathrm{~g}$ of soil, which had an average bulk density of $1.6 \mathrm{~g} \mathrm{~cm}^{-3}$ (Figure 2). There was no soil in the top $20 \mathrm{~cm}$ of the columns.

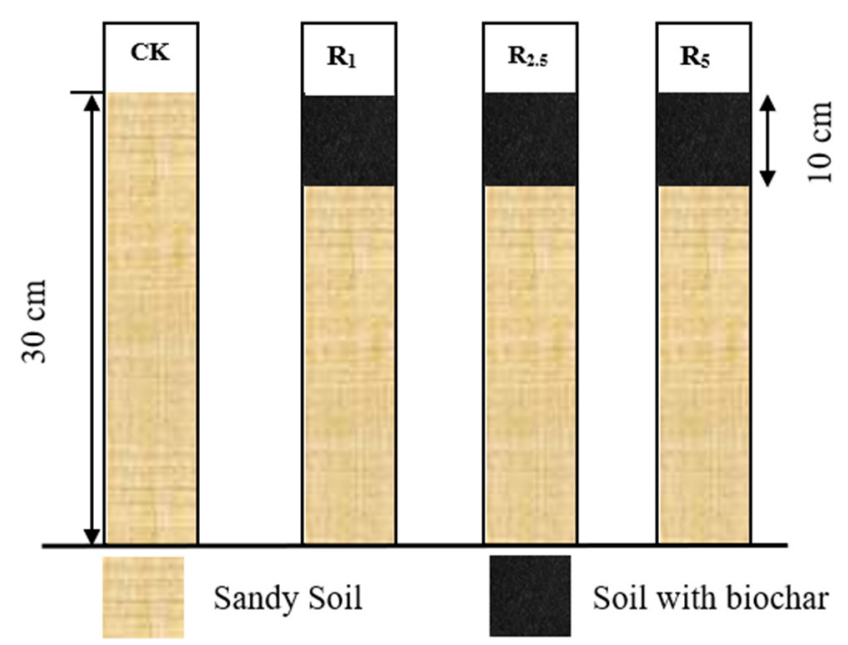

Figure 2. A diagram of the experiment illustrating the layers of soil and biochar.

Biochar treatments are shown in Table 2. Biochar mixtures were added to the top $10 \mathrm{~cm}$ of each column in three and application rates were $1 \%, 2.5 \%$, and $5 \%\left(10,25,50 \mathrm{~g} \mathrm{Kg}^{-1}\right.$ soil, respectively). Columns were placed vertically in a wooden holder inside a laboratory room, where the temperature was $22 \pm 3{ }^{\circ} \mathrm{C}$.

Table 2. Biochar treatments applied in the experiments.

\begin{tabular}{|c|c|c|c|c|c|}
\hline Temperature $\left({ }^{\circ} \mathrm{C}\right)$ & Diameter (mm) & Application Rate (\%) & Code & Symbol & Replicates \\
\hline \multirow{9}{*}{300} & \multirow{3}{*}{0.5} & 1 & $\mathrm{~T}_{300} \mathrm{D}_{0.5} \mathrm{R}_{1}$ & $\mathrm{~T} 1$ & 3 \\
\hline & & 2.5 & $\mathrm{~T}_{300} \mathrm{D}_{0.5} \mathrm{R}_{2.5}$ & T2 & 3 \\
\hline & & 5 & $\mathrm{~T}_{300} \mathrm{D}_{0.5} \mathrm{R}_{5}$ & T3 & 3 \\
\hline & \multirow{3}{*}{1} & 1 & $\mathrm{~T}_{300} \mathrm{D}_{1} \mathrm{R}_{1}$ & $\mathrm{~T} 4$ & 3 \\
\hline & & 2.5 & $\mathrm{~T}_{300} \mathrm{D}_{1} \mathrm{R}_{2.5}$ & T5 & 3 \\
\hline & & 5 & $\mathrm{~T}_{300} \mathrm{D}_{1} \mathrm{R}_{5}$ & T6 & 3 \\
\hline & \multirow{3}{*}{2} & 1 & $\mathrm{~T}_{300} \mathrm{D}_{2} \mathrm{R}_{1}$ & $\mathrm{~T} 7$ & 3 \\
\hline & & 2.5 & $\mathrm{~T}_{300} \mathrm{D}_{2} \mathrm{R}_{2.5}$ & T8 & 3 \\
\hline & & 5 & $\mathrm{~T}_{300} \mathrm{D}_{2} \mathrm{R}_{5}$ & T9 & 3 \\
\hline
\end{tabular}


Table 2. Cont.

\begin{tabular}{|c|c|c|c|c|c|}
\hline Temperature $\left({ }^{\circ} \mathrm{C}\right)$ & Diameter (mm) & Application Rate (\%) & Code & Symbol & Replicates \\
\hline \multirow{9}{*}{500} & \multirow{3}{*}{0.5} & 1 & $\mathrm{~T}_{500} \mathrm{D}_{0.5} \mathrm{R}_{1}$ & T10 & 3 \\
\hline & & 2.5 & $\mathrm{~T}_{500} \mathrm{D}_{0.5} \mathrm{R}_{2.5}$ & $\mathrm{~T} 11$ & 3 \\
\hline & & 5 & $\mathrm{~T}_{500} \mathrm{D}_{0.5} \mathrm{R}_{5}$ & $\mathrm{~T} 12$ & 3 \\
\hline & \multirow{3}{*}{1} & 1 & $\mathrm{~T}_{500} \mathrm{D}_{1} \mathrm{R}_{1}$ & $\mathrm{~T} 13$ & 3 \\
\hline & & 2.5 & $\mathrm{~T}_{500} \mathrm{D}_{1} \mathrm{R}_{2.5}$ & $\mathrm{~T} 14$ & 3 \\
\hline & & 5 & $\mathrm{~T}_{500} \mathrm{D}_{1} \mathrm{R}_{5}$ & $\mathrm{~T} 15$ & 3 \\
\hline & \multirow{3}{*}{2} & 1 & $\mathrm{~T}_{500} \mathrm{D}_{2} \mathrm{R}_{1}$ & T16 & 3 \\
\hline & & 2.5 & $\mathrm{~T}_{500} \mathrm{D}_{2} \mathrm{R}_{2.5}$ & $\mathrm{~T} 17$ & 3 \\
\hline & & 5 & $\mathrm{~T}_{500} \mathrm{D}_{2} \mathrm{R}_{5}$ & $\mathrm{~T} 18$ & 3 \\
\hline \multirow{10}{*}{700} & \multirow{3}{*}{0.5} & 1 & $\mathrm{~T}_{700} \mathrm{D}_{0.5} \mathrm{R}_{1}$ & T19 & 3 \\
\hline & & 2.5 & $\mathrm{~T}_{700} \mathrm{D}_{0.5} \mathrm{R}_{2.5}$ & $\mathrm{~T} 20$ & 3 \\
\hline & & 5 & $\mathrm{~T}_{700} \mathrm{D}_{0.5} \mathrm{R}_{5}$ & $\mathrm{~T} 21$ & 3 \\
\hline & \multirow{3}{*}{1} & 1 & $\mathrm{~T}_{700} \mathrm{D}_{1} \mathrm{R}_{1}$ & $\mathrm{~T} 22$ & 3 \\
\hline & & 2.5 & $\mathrm{~T}_{700} \mathrm{D}_{1} \mathrm{R}_{2.5}$ & $\mathrm{~T} 23$ & 3 \\
\hline & & 5 & $\mathrm{~T}_{700} \mathrm{D}_{1} \mathrm{R}_{5}$ & $\mathrm{~T} 24$ & 3 \\
\hline & \multirow{3}{*}{2} & 1 & $\mathrm{~T}_{700} \mathrm{D}_{2} \mathrm{R}_{1}$ & $\mathrm{~T} 25$ & 3 \\
\hline & & 2.5 & $\mathrm{~T}_{700} \mathrm{D}_{2} \mathrm{R}_{2.5}$ & $\mathrm{~T} 26$ & 3 \\
\hline & & 5 & $\mathrm{~T}_{700} \mathrm{D}_{2} \mathrm{R}_{5}$ & $\mathrm{~T} 27$ & 3 \\
\hline & \multicolumn{2}{|c|}{ CK } & & CK & 3 \\
\hline
\end{tabular}

(T) temperature, (D) diameter, (R) application rate and (CK) Control.

\subsection{Cumulative Evaporation}

Every week, $25 \mathrm{~mL}$ of tap water $\left(\mathrm{EC}=1.4 \mathrm{dS} \mathrm{m}^{-1}\right)$ was added to the columns. Water was added for six weeks (six cycles) and there were three replicates for each treatment for total number 84 columns in the experiment. Cumulative evaporation was measured daily by weighing each soil column. At the end of the six cycles, each column was divided into sections: three sections from the top $(10 \mathrm{~cm})$ layer of the column and 4 layers $(5 \mathrm{~cm})$ sections from the remainder $(20 \mathrm{~cm})$ of the column.

\subsection{Cumulative Infiltration}

Infiltration was measured with a mini-disk infiltrometer that held $100 \mathrm{~cm}^{3}$ water (model M11, $0.5 \mathrm{~cm}$ suction; Decagon Devices, Pullman, WA, USA). The disk infiltrometer was in full contact with the soil surface before measurements were taken. The volume of water infiltrated was recorded every $30 \mathrm{~s}$ for $10 \mathrm{~min}$. Each treatment was replicated three times. Cumulative infiltration was based on the Philip (1957) equation, shown in Equation (1), and the infiltration rate (i) was established by Equation (2).

$$
I=S \sqrt{t}+A t
$$

where: I the cumulative infiltration $(\mathrm{cm}), \mathrm{S}$ is the sorptivity $\left(\mathrm{cm} \mathrm{min}^{-0.5}\right)$, and $\mathrm{A}$ is a constant related to the hydraulic conductivity. A mathematical representation for Equation (1) obtained by plotting cumulative infiltration versus the square root of time, and a secondorder polynomial fitted to the measured data.

$$
\mathrm{i}=\frac{1}{2} \mathrm{~S} \mathrm{t}^{-\frac{1}{2}}+\mathrm{A}
$$

obtained a mathematical representation for Equation (2) by plotting infiltration rate versus $1 /\left(2 t^{0.5}\right)$ and fitting a linear equation to the measured data. 


\subsection{Saturated Hydraulic Conductivity $\left(K_{S}\right)$}

Saturated hydraulic conductivity $\left(\mathrm{K}_{\mathrm{S}}\right)$ was measured by the constant head method and, calculated according Darcy's equation, (3):

$$
\mathrm{K}_{\mathrm{S}}=\frac{\mathrm{V} 1}{\mathrm{At}(1+\mathrm{h})}
$$

where Ks is the saturated hydraulic conductivity $\left(\mathrm{cm} \mathrm{s}^{-1}\right), \mathrm{V}$ is the volume of outflow $\left(\mathrm{cm}^{3}\right), 1$ is the length of soil column (cm), A is the cross-sectional area of the soil column $\left(\mathrm{cm}^{2}\right), \mathrm{t}$ is time $(\mathrm{s})$, and $\mathrm{h}$ is the constant head of water $(\mathrm{cm})$.

\subsection{Statistical Analysis}

Means were determined. Statistical analyses were carried out using ANOVA and the least significant difference (LSD at $p<0.05$ ) was determined using the software package for Windows (IBM SPSS Statistics 21 Core System, IBM Corporation 2019).

\section{Results and Discussion:}

\subsection{Cumulative Evaporation}

3.1.1. Influence of Temperature of Pyrolysis

Figure 3 shows the influence of the pyrolytic temperature and different application rates on cumulative evaporation. The total amount of water applied to the soil columns throughout all the experiment was $94.36 \mathrm{~mm}$. Compared to the control, addition of biochar at the rate of $1 \%$ and produced at the three different temperatures led to an increase in cumulative evaporation by $13.5 \%, 15.2 \%$, and $1.9 \%$ for treatments $\mathrm{T}_{300}, \mathrm{~T}_{500}$, and $\mathrm{T}_{700}$, respectively (Figure $3 \mathrm{a}$ ), the increased was in specific period of evaporation cycles (especially in 15-42 days). Compared to the untreated soil Addition of biochar at the rate of $2.5 \%(w / w)$ at the three temperatures (Figure $3 b$ ) decreased the cumulative evaporation by $15.1 \%, 12.6 \%$ and $12.1 \%$ for treatments $\mathrm{T}_{300}, \mathrm{~T}_{500}$, and $\mathrm{T}_{700}$, respectively. However, the application of the biochar with high rate $5 \%(w / w)$ increased the cumulative evaporation by $12.2 \%$ and $15.7 \%$ for $\mathrm{T}_{300}$ and $\mathrm{T}_{500}$, respectively (Figure $3 \mathrm{c}$ ). Addition of biochar with highest pyrolytic temperature and highest rate $\left(T_{700}-R_{5}\right)$ decreased cumulative evaporation by $5.32 \%$. These finding could be attributed to the influences of the temperature of pyrolysis on the physical and chemical properties of the biochar and decomposition of its structure and chemical bonds. The increase of cumulative evaporation could be due to the fact that addition of biochar produced at lower pyrolytic temperatures could retain more water, which caused an increase in evaporation, especially because the biochar was placed in the top of columns. Retained water tends to be lost due to the high porosity of the biochar that has macropores $[20,21]$. This also could be due to the effect of pyrolytic temperature on biochar stability [22]. An increase of temperature of pyrolysis could affect the availability of elements like nitrogen [23]. Domingues et al. [24]. reported that an increase in biochar pyrolytic temperature from $450{ }^{\circ} \mathrm{C}$ to $750{ }^{\circ} \mathrm{C}$ decreased the cation exchange capacity that resulted in reduction in adsorption capacity of nutrients. A high temperature of pyrolysis might decrease pore volume and surface area and increase the ash content of biochar [25,26]. A low pyrolytic temperature is an important factor that could increase nutrient availability and functional groups [27]. 

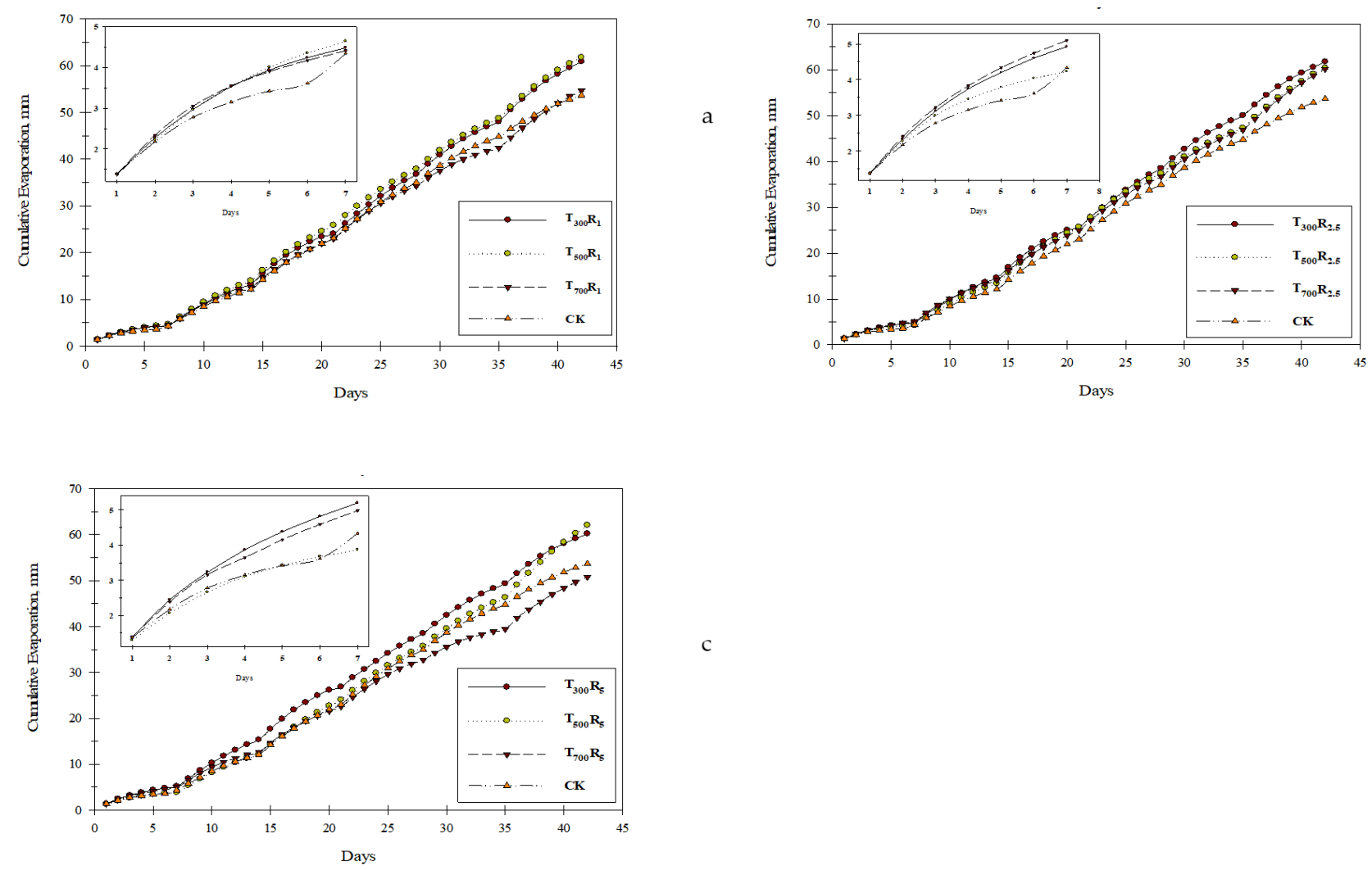

Figure 3. Influence of temperature of pyrolysis on cumulative evaporation at different application rates (a) $R_{1}$ or $1 \%$, (b) $R_{2.5}$ or $2.5 \%$ and (c) $R_{5}$ or $5 \%$.

\subsubsection{Effect of Application Rate}

Biochar reduced cumulative evaporation significantly $(p>0.05)$, when it was added at a high rate compared to the control, when biochar produced at a pyrolytic temperature of $300{ }^{\circ} \mathrm{C}$ was added with different rates, cumulative evaporation decreased in all of the cycles at all application rate tested by $1.4 \%, 5.4 \%$, and $8.3 \%$ for rates $1 \%, 2.5 \%$, and $5 \%$ $(w / w)$, respectively (Figure $4 a)$. When biochar produced at a pyrolytic temperature of $500{ }^{\circ} \mathrm{C}$ was added, cumulative evaporation decreased non-significantly by $1.4 \%, 0.42 \%$, and $2.3 \%$ for of $1 \%, 2.5 \%$ and $5 \%(w / w)$ as the rates, respectively (Figure $4 \mathrm{~b}$ ). When biochar produced at a pyrolytic temperature of $700{ }^{\circ} \mathrm{C}$ (Figure $4 \mathrm{c}$ ) and different dose $1 \%, 2.5 \%$, and $5 \%(w / w)$ cumulative evaporation decreased by $7.4 \%, 4.1 \%$, and $14.6 \%$ respectively (Figure 4c). Alkhasha et al. [28] found that cumulative evaporation was reduced by $29.4 \%$ and $14.6 \%$ when biochar was added at the high rates of $4 \%$ and $8 \%$, respectively. This could be due to enhanced water retention by biochar and the reduction in macrospores of the sandy soil that they studied.

\subsubsection{Impact of Diameter of Biochar}

When biochar produced at a pyrolytic temperature of $300{ }^{\circ} \mathrm{C}$ was added, cumulative evaporation was increased $(p>0.05)$. The proportion of increased was $7.2 \%$ to $7.5 \%$ when the diameter of the biochar increased from $<0.5 \mathrm{~mm}$ (D1) to 0.5 to $1.0 \mathrm{~mm}$ (D2) (Figure 5a). Compared to the control, cumulative evaporation increased $1.6 \%$ when biochar with a diameter $<0.5 \mathrm{~mm}$ was added. Biochar produced at $500{ }^{\circ} \mathrm{C}$ (Figure $5 \mathrm{~b}$ ) was added, the cumulative evaporation increased by $5.7 \%, 8.2 \%$, and $8.11 \%$ for diameters less than $0.5 \mathrm{~mm}$, $0.5-1 \mathrm{~mm}$, and $1-2 \mathrm{~mm}$, respectively. (Figure $5 \mathrm{c}$ ) shown biochar produced at a pyrolytic temperature of $700{ }^{\circ} \mathrm{C}$ was added, cumulative evaporation decreased by $5.0 \%$ and $0.49 \%$ for diameters $<0.5 \mathrm{~mm}$ and $1-2 \mathrm{~mm}$, respectively, while cumulative evaporation increased non-significantly $0.27 \%$ when biochar with a diameter of 0.5 to $1 \mathrm{~mm}$ was added. Herath et al. [29] showed that the reduction of pores was correlated with the biochar application 
rate. Their detailed analysis of the soil pore system showed that some pore fractions were dependent not only on the rate of the biochar but also on its particle size. Mukherjee and Lal [30] showed that small particles of biochar reduced the volume of soil pores whose diameter was below $0.5 \mu \mathrm{m}$ but increased the volume of larger pores with a diameter range between $0.5-500 \mu \mathrm{m}$.

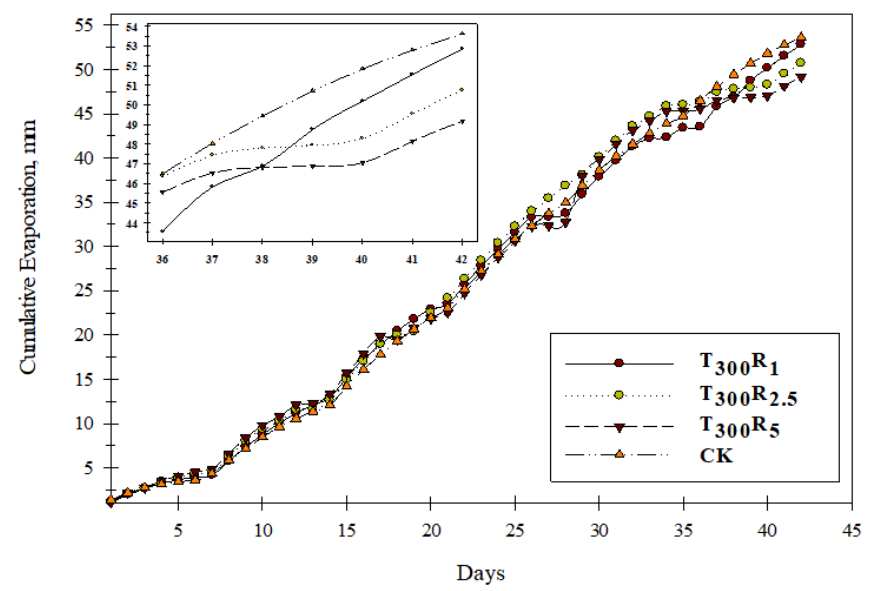

a

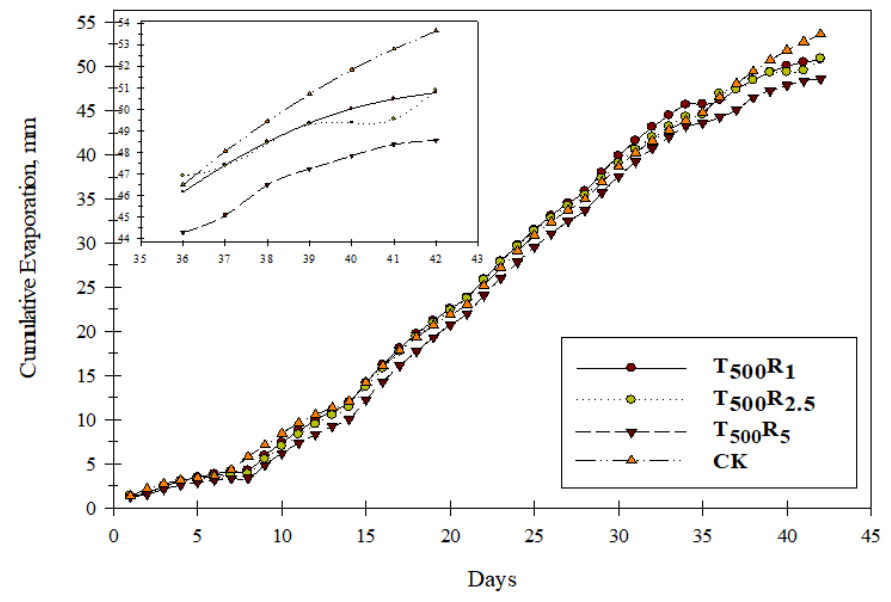

b

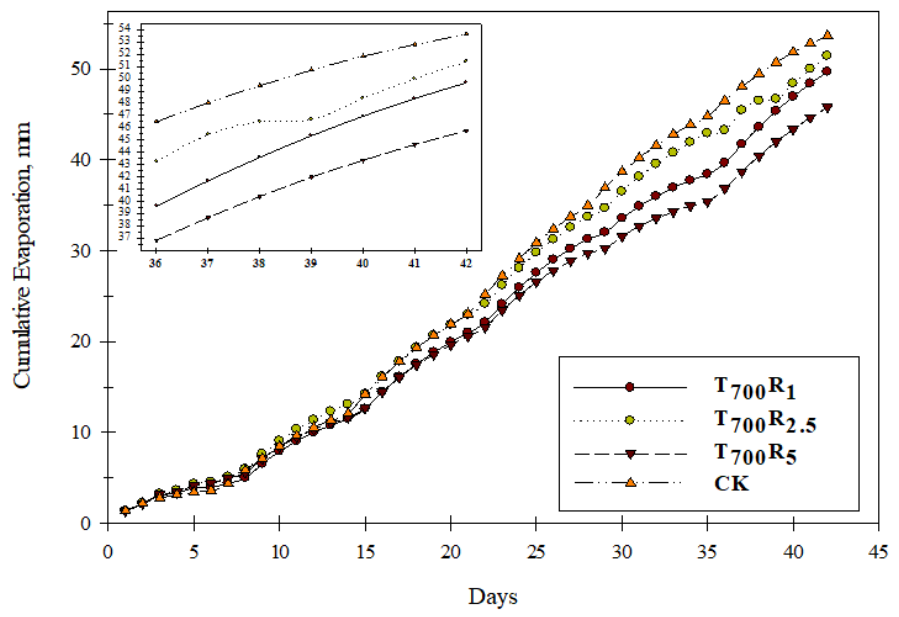

$\mathrm{C}$

Figure 4. Effect of application rate with different temperatures of pyrolysis on cumulative evaporation: (a) $\mathrm{T}_{300}$, (b) $\mathrm{T}_{500}$ and (c) $\mathrm{T}_{700}$. 


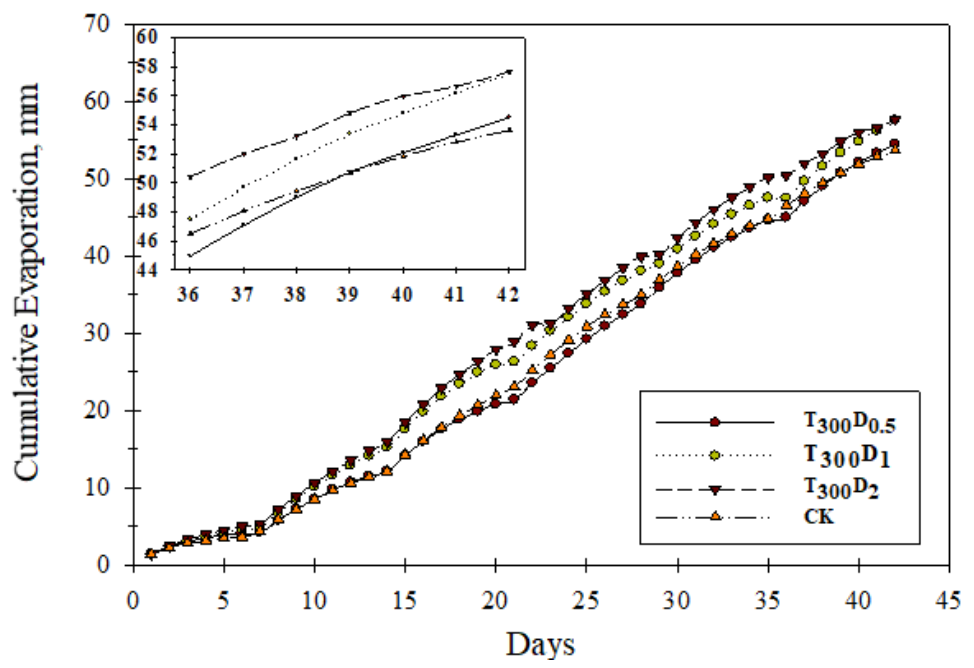

a

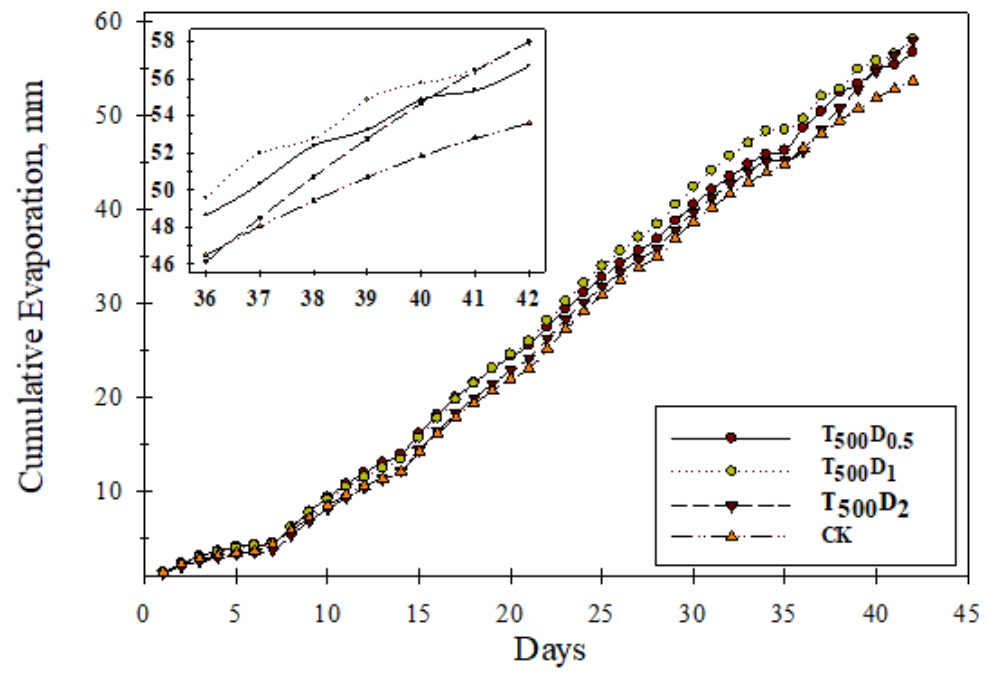

$\mathrm{b}$

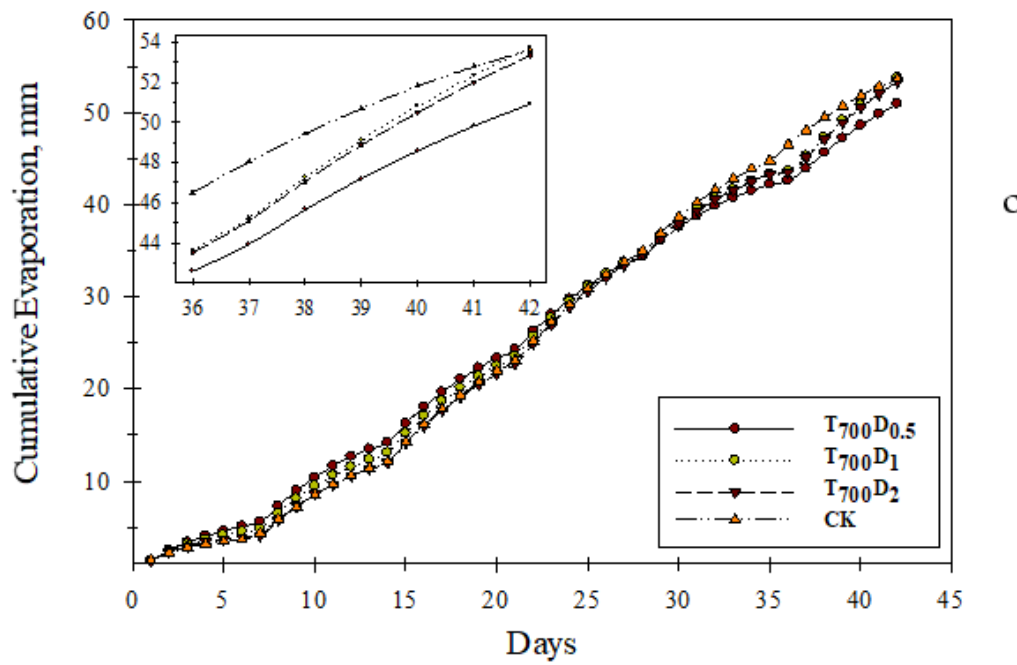

Figure 5. Effect of different diameters on cumulative evaporation: (a) $\mathrm{T}_{300}$, (b) $\mathrm{T}_{500}$ and (c) $\mathrm{T}_{700}$.

\subsection{Saturated Hydraulic Conductivity}

When biochar produced at a pyrolytic temperature of $300{ }^{\circ} \mathrm{C}$ was added, saturated hydraulic conductivity decreased significantly $(p<0.05)$ for all treatments (T1 to T9) (Figure 6a). Compared to the control, the highest decreases were $94.55 \%$ and $81.6 \%$ for T3 $(<0.5 \mathrm{~mm}$ diameter; application rate of $5 \%)$ and T2 $(<0.5 \mathrm{~mm}$ diameter; application rate of 
$2.5 \%)$, respectively. Compared to the control, the lowest decreases were $22.98 \%$ and $28.31 \%$ for T9 (1-2 mm diameter; application rate of 5\%) and T8 (1-2 mm diameter; application rate of $2.5 \%)$, respectively.

a
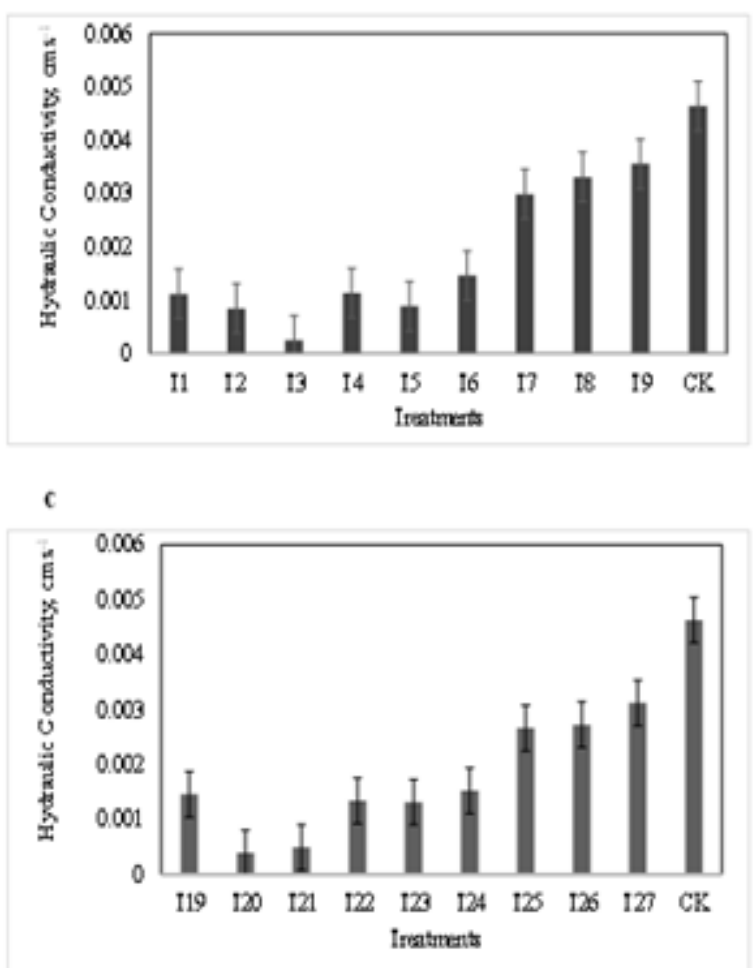

b

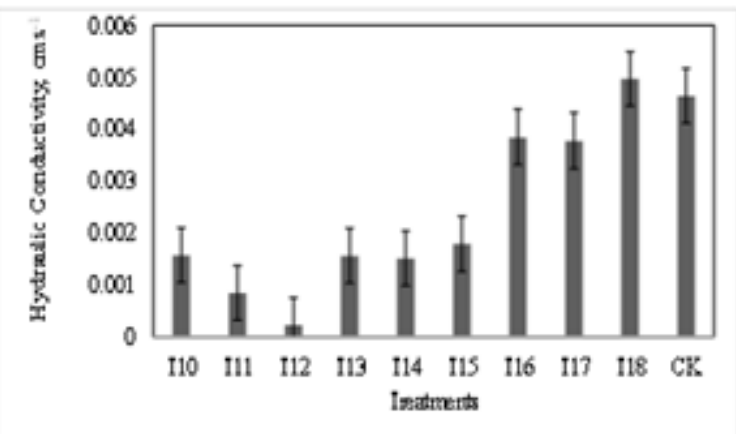

Figure 6. Effect of application rate and particle size of biochar on saturated hydraulic conductivity, (a) biochar at $300{ }^{\circ} \mathrm{C}$, (b) $500{ }^{\circ} \mathrm{C}$ and (c) $700^{\circ} \mathrm{C}$.

When biochar produced at a pyrolytic temperature of $500{ }^{\circ} \mathrm{C}$ was added, Ks decreased in $\mathrm{T} 10$ to $\mathrm{T} 17$, and the decrease varied between $16.8 \%$ and $94.9 \%$ for $\mathrm{T} 16$ and $\mathrm{T} 12$, respectively (Figure 6b). Compared with the untreated soil, Ks increased by $7.1 \%$ in T18 (diameter of 1-2 mm and application rate of $5 \%$ ). When biochar produced at a pyrolytic temperature of $700{ }^{\circ} \mathrm{C}$ was added, Ks decreased significantly $(p<0.05)$ compared with the control. The decreases were $68.5 \%, 91.6 \%, 89.4 \%, 71.0 \%, 71.6 \%, 67.1 \%, 42.4 \%, 41.2 \%$ and $32.6 \%$ for $\mathrm{T} 19$ to T27, respectively. Compared to the control, the highest decreases were $91.6 \%$ and $89.4 \%$ for T20 ( $<0.5 \mathrm{~mm}$ diameter and 2.5\% application rate) and T21 $<0.5 \mathrm{~mm}$ diameter and 5\% application rate), respectively. The decease of Ks could be attributed to the rearrangement of soil particles and the formation of micro-porosity. These results were similar to those reported earlier [31-33]. Since the biochar decrease saturated hydraulic conductivity of soils, it can be prevented groundwater contaminations especially in high temperature of arid environment $[34,35]$.

\subsection{Cumulative Infiltration and Infiltration Rate}

When biochar produced at a pyrolytic temperature of $300{ }^{\circ} \mathrm{C}$, cumulative infiltration decreased significantly, and its percentage decrease varied from $6.7 \%$ to $60.3 \%$ for $\mathrm{T} 9$ and T1, respectively (Figure 7a). The highest decreases were 50.0\% (T1), 51.0\% (T2), and $60.3 \%$ (T3). All treatments had the fine particle size (diameter $<0.5 \mathrm{~mm}$ ) and the rates of addition were $2.5 \%$ (T2), $5 \%$ (T3), and $1 \%$ (T1). Similar results were found for the infiltration rate with the same percentages of decrease (Figure 8a). The lowest decrease was for the large particle size (diameter 1-2 mm). Compared with the non-treated soil, cumulative infiltration and infiltration rate were reduced by $6.7 \%, 29.9 \%$, and $29.9 \%$ for $\mathrm{T} 7, \mathrm{~T} 8$, and 
$\mathrm{T} 9$, respectively. For biochar produced at the pyrolytic temperature of $500{ }^{\circ} \mathrm{C}$, cumulative infiltration and infiltration rate were enhanced by biochar application (Figures $7 \mathrm{~b}$ and $8 \mathrm{~b}$ ). For T11 ( $<0.5 \mathrm{~mm}$ diameter; $2.5 \%$ application rate) and T18 (1-2 mm diameter and 5\% application rate), the decreases were $19.1 \%$ and $64.9 \%$, respectively. For biochar produced at the pyrolytic temperature of $700{ }^{\circ} \mathrm{C}$, and the percentages of the decrease for cumulative infiltration compared to the control were $57.2 \%, 48.9 \%, 49.5 \%, 51.0 \%, 18.6 \%, 4.1 \%, 42.8 \%$, $15.5 \%$ and $1.0 \%$ for T19 to T27, respectively (See Appendix A). These results could be due to the fact that the biochar has fine particles that filled or clogged soil macrospores. Hence, pathways for conduction of water were reduced due to the interaction of biochar with soil matrix in water. However, under these conditions, water in the root-zone would not be lost due to deep percolation and there should be more available water for plant growth. Similar results were reported earlier by various researchers $[4,9,27,36-46]$.

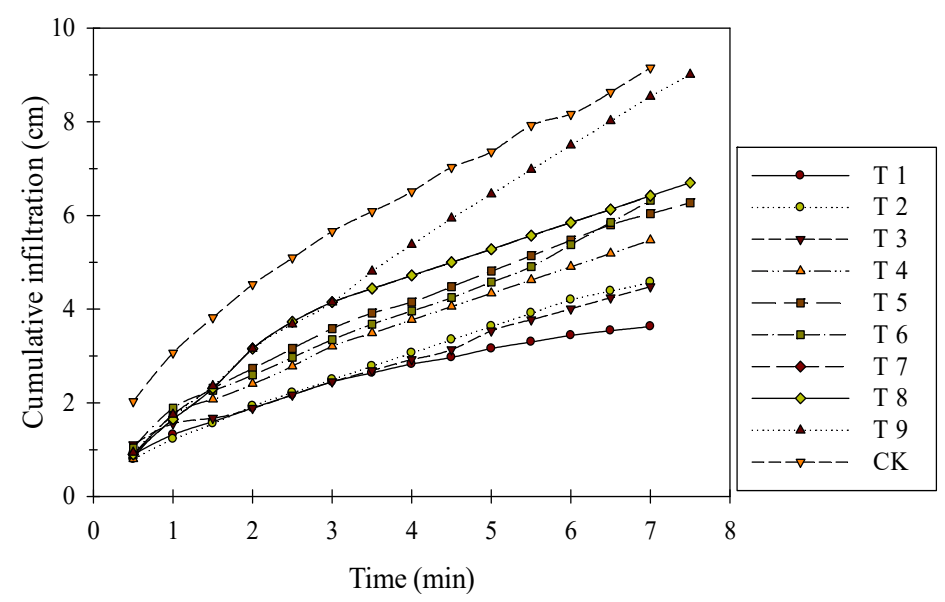

(a)

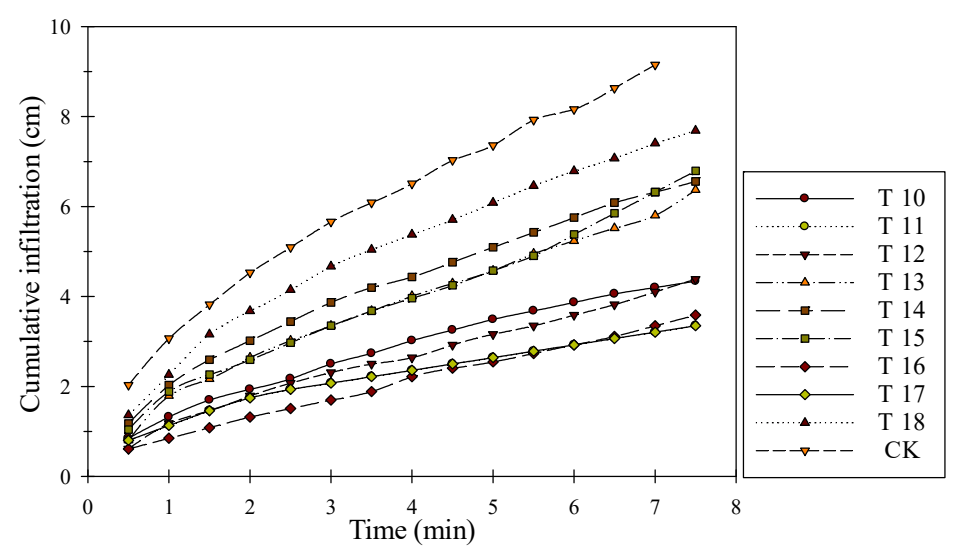

(b)

Figure 7. Cont. 


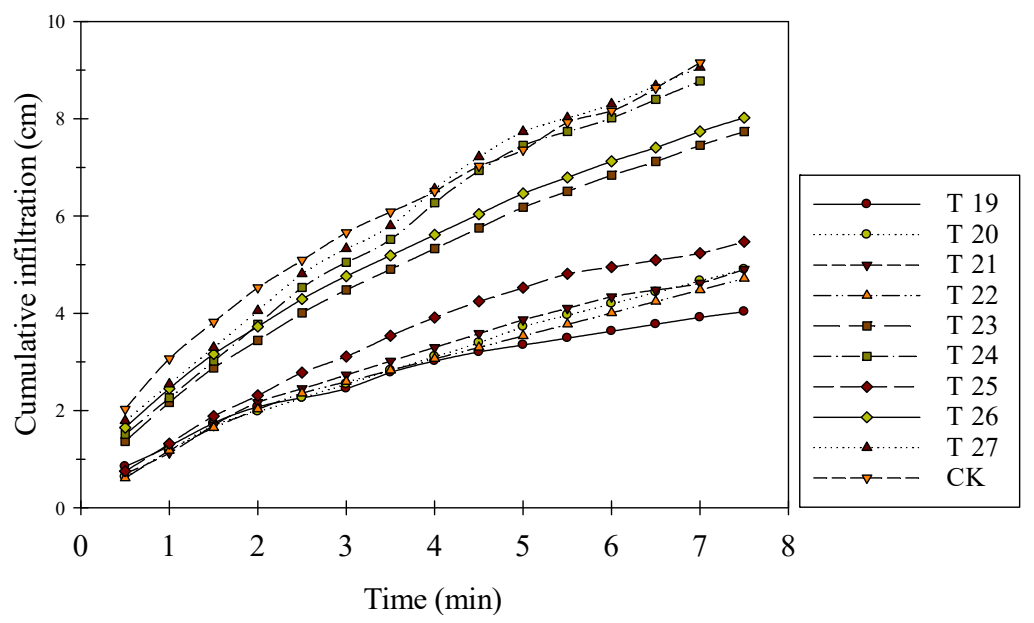

(c)

Figure 7. Effect of application rate and particle size of biochar on cumulative infiltration, (a) biochar at $300{ }^{\circ} \mathrm{C}$, (b) $500{ }^{\circ} \mathrm{C}$ and (c) $700{ }^{\circ} \mathrm{C}$.

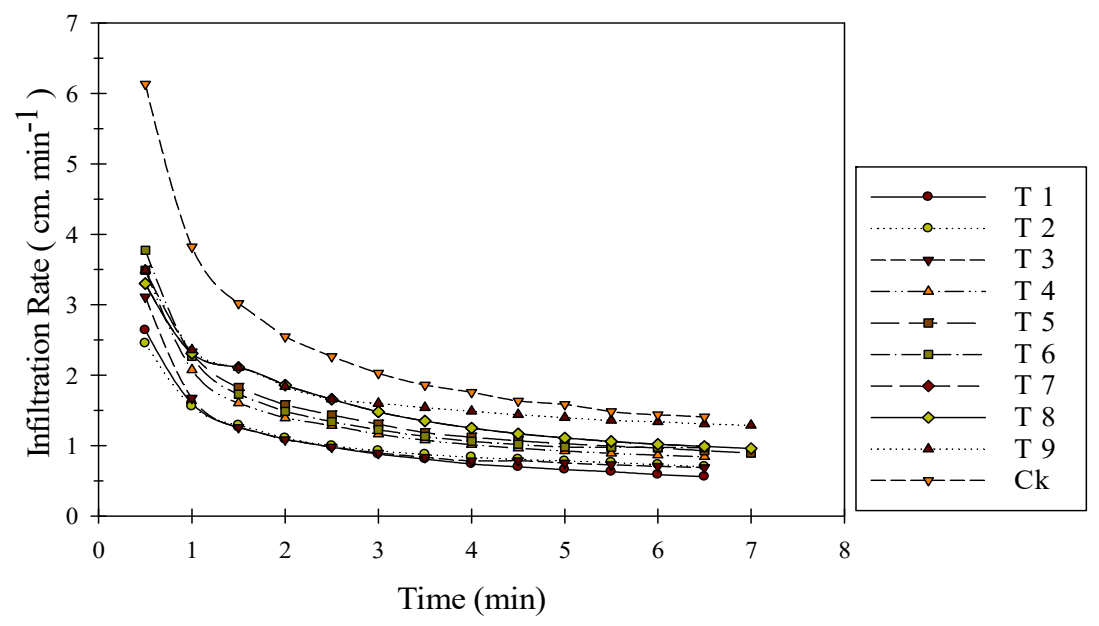

(a)

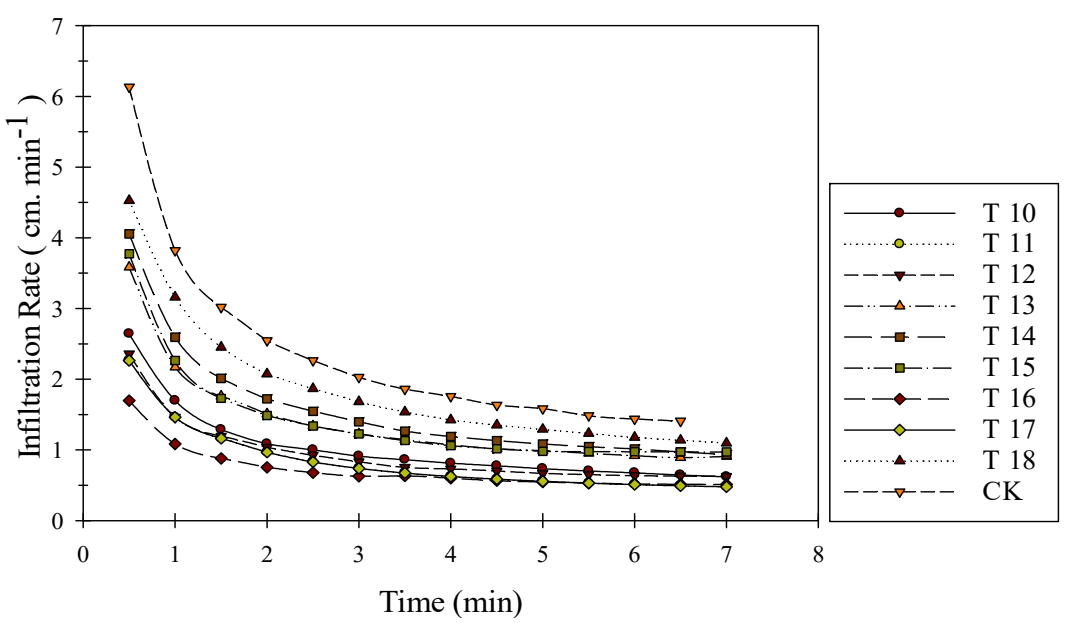

(b)

Figure 8. Cont. 


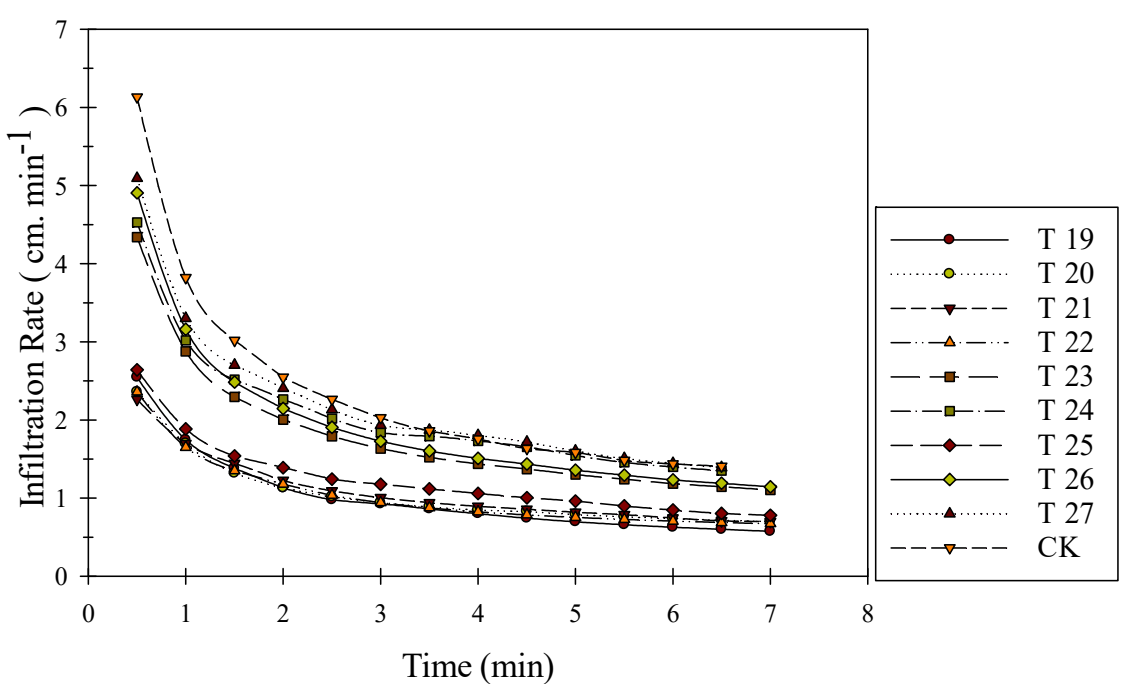

(c)

Figure 8. Effect of application rate and particle size of biochar on infiltration rate, (a) biochar at $300{ }^{\circ} \mathrm{C}$, (b) $500{ }^{\circ} \mathrm{C}$ and (c) $700{ }^{\circ} \mathrm{C}$.

\section{Conclusions}

The biochar was generally used as an amendment in a coarse soil. Consequently, the impacts of pyrolytic temperature $\left(300,500\right.$, and $\left.700{ }^{\circ} \mathrm{C}\right)$, particle size $(1-2 \mathrm{~mm}, 0.5-1 \mathrm{~mm}$, and less than $0.5 \mathrm{~mm})$, and application rates $(1 \%, 2.5 \%$, and $5 \%$ weight/weight) of biochar on hydro-physical properties of calcareous sandy soil were investigated in column experiment. The findings of this study demonstrated significant decrease in cumulative evaporation and saturated hydraulic conductivity. It was revealed that the saturated hydraulic conductivity was declined from $23.0 \%$ to $94.6 \%$ with biochar application produced at $300{ }^{\circ} \mathrm{C}, 16.8 \%$ to $94.9 \%$ for biochar produced at $500{ }^{\circ} \mathrm{C}$, and $32.7 \%$ to $92.0 \%$ for biochar produced at $700{ }^{\circ} \mathrm{C}$, respectively. Application of biochar resulted in decreased cumulative infiltration and infiltration rate. The reduction was probably due to the fact that the fine particles of the biochar filled the micropores and increased micro-porosity. The highest improvements in hydro-physical properties of soils were observed when biochar with particle size of $0.5-1 \mathrm{~mm}$ was applied at low rate (1\%). i.e., when biochar produced at a pyrolytic temperature of $300{ }^{\circ} \mathrm{C}$, cumulative infiltration decreased significantly, and its percentage decrease varied from $6.7 \%$ to $60.3 \%$. The highest decreases were $50.0 \%$ (T1), $51.0 \%$ (T2), and $60.3 \%$ (T3). Overall, the findings of this study demonstrated that the biochar can significantly improve the hydrological and physical properties of the calcareous sandy soil depending upon pyrolytic temperature, particle size, and application rate of biochar.

Author Contributions: Conceptualization, supervision, funding acquisition: A.G.A. and A.A.-O.; Methodology, formal analysis and investigation, original draft preparation: A.G.A. and A.A.-O.; Resources management, data acquisition, statistical analyses, manuscript review and editing: A.A., Data analyses, Statistical analyses: Z.A., Manuscript review and editing: A.A.A. All authors have read and agreed to the published version of the manuscript.

Funding: This project was funded by the National Plan for Science, Technology and Innovation (MAARIFAH), King Abdulaziz City for Science and Technology, Kingdom of Saudi Arabia, Award Number (15-AGR4704-02).

Institutional Review Board Statement: Not applicable.

Informed Consent Statement: Not applicable.

Data Availability Statement: Data is contained within the article. 
Acknowledgments: The authors would like to thank the National Plan for Science, Technology and Innovation (MAARIFAH), King Abdulaziz City for Science and Technology, Kingdom of Saudi Arabia, Award Number (15-AGR4704-02) for supporting this work.

Conflicts of Interest: The authors declare no conflict of interest.

Appendix A. Equations Describing Cumulative Infiltration and Infiltration Rate

\begin{tabular}{|c|c|c|c|c|}
\hline \multirow{2}{*}{$\frac{\mathbf{T}}{\mathrm{T} 1}$} & \multicolumn{2}{|c|}{ Cumulative Evaporation } & \multicolumn{2}{|c|}{ Infiltration Rate } \\
\hline & $y=1.4534 x-0.1251$ & $R^{2}=0.9975$ & $y=2.2256 x+0.4664$ & $R^{2}=0.9925$ \\
\hline $\mathrm{T} 2$ & $y=2.0124 x-0.8518$ & $\mathrm{R}^{2}=0.9912$ & $y=1.8796 x+0.6048$ & $R^{2}=0.9967$ \\
\hline T3 & $y=1.7679 x-0.4352$ & $\mathrm{R}^{2}=0.9708$ & $y=2.5837 x+0.4678$ & $\mathrm{R}^{2}=0.9961$ \\
\hline $\mathrm{T} 4$ & $y=3.0158 x+0.5561$ & $\mathrm{R}^{2}=0.9174$ & $y=2.3214 x-0.7994$ & $R^{2}=0.9959$ \\
\hline $\mathrm{T} 5$ & $y=2.6133 x-0.95$ & $\mathrm{R}^{2}=0.9982$ & $y=2.8205 x+0.7835$ & $\mathrm{R}^{2}=0.9886$ \\
\hline $\mathrm{T} 6$ & $y=2.5537 x-0.9322$ & $R^{2}=0.9786$ & $y=3.2641 x+0.5948$ & $R^{2}=0.9192$ \\
\hline $\mathrm{T} 7$ & $y=2.8297 x-0.9942$ & $R^{2}=0.9929$ & $y=2.7413 x+0.8407$ & $\mathrm{R}^{2}=0.8009$ \\
\hline $\mathrm{T} 8$ & $y=2.8212 x-0.9816$ & $R^{2}=0.9938$ & $y=2.5538 x+0.9527$ & $\mathrm{R}^{2}=0.9352$ \\
\hline $\mathrm{T} 9$ & $y=4.0581 x-2.4953$ & $\mathrm{R}^{2}=0.9885$ & $y=2.3642 x+1.181$ & $\mathrm{R}^{2}=0.9919$ \\
\hline $\mathrm{T} 10$ & $y=1.7664 x-0.495$ & $\mathrm{R}^{2}=0.9971$ & $y=2.1745 x+0.528$ & $\mathrm{R}^{2}=0.9941$ \\
\hline $\mathrm{T} 11$ & $y=1.2225 x-0.0518$ & $R^{2}=0.9976$ & $y=1.965 x+0.3926$ & $\mathrm{R}^{2}=0.9845$ \\
\hline $\mathrm{T} 12$ & $y=1.7705 x-0.7166$ & $R^{2}=0.9896$ & $y=1.8908 x+0.5051$ & $\mathrm{R}^{2}=0.9954$ \\
\hline $\mathrm{T} 13$ & $y=2.5563 x-0.9953$ & $\mathrm{R}^{2}=0.9927$ & $y=2.9078 x+0.7172$ & $\mathrm{R}^{2}=0.9972$ \\
\hline $\mathrm{T} 14$ & $y=2.6133 x-0.6669$ & $R^{2}=0.9982$ & $y=3.3867 x+0.7835$ & $\mathrm{R}^{2}=0.9921$ \\
\hline $\mathrm{T} 15$ & $y=2.6662 x-1.0981$ & $\mathrm{R}^{2}=0.9723$ & $y=3.0739 x+0.7083$ & $R^{2}=0.9991$ \\
\hline $\mathrm{T} 16$ & $y=1.4839 x-0.7078$ & $\mathrm{R}^{2}=0.9802$ & $y=1.2875 x+0.4263$ & $R^{2}=0.9981$ \\
\hline $\mathrm{T} 17$ & $y=1.2225 x-0.0518$ & $R^{2}=0.9976$ & $y=1.965 x+0.3926$ & $\mathrm{R}^{2}=0.9845$ \\
\hline $\mathrm{T} 18$ & $y=3.0665 x-0.72$ & $\mathrm{R}^{2}=0.999$ & $y=3.7874 x+0.9799$ & $\mathrm{R}^{2}=0.9753$ \\
\hline $\mathrm{T} 19$ & $y=1.5823 x-0.227$ & $R^{2}=0.9968$ & $y=2.1588 x+0.5197$ & $\mathrm{R}^{2}=0.9756$ \\
\hline $\mathrm{T} 20$ & $y=2.0988 x-0.9671$ & $R^{2}=0.9953$ & $y=1.8356 x+0.6277$ & $\mathrm{R}^{2}=0.9813$ \\
\hline $\mathrm{T} 21$ & $y=2.099 x-0.8621$ & $\mathrm{R}^{2}=0.9984$ & $y=1.7311 x+0.6842$ & $\mathrm{R}^{2}=0.9497$ \\
\hline $\mathrm{T} 22$ & $y=1.9711 x-0.8006$ & $R^{2}=0.9977$ & $y=1.8635 x+0.6077$ & $\mathrm{R}^{2}=0.9755$ \\
\hline $\mathrm{T} 23$ & $y=3.1899 x-1.0057$ & $\mathrm{R}^{2}=0.9994$ & $y=3.4941 x+0.9935$ & $\mathrm{R}^{2}=0.9861$ \\
\hline $\mathrm{T} 24$ & $y=3.951 x-1.6413$ & $R^{2}=0.9946$ & $y=3.6777 x+1.0836$ & $\mathrm{R}^{2}=0.8374$ \\
\hline $\mathrm{T} 25$ & $y=2.4232 x-1.0245$ & $\mathrm{R}^{2}=0.9956$ & $y=1.9846 x+0.7801$ & $\mathrm{R}^{2}=0.966$ \\
\hline $\mathrm{T} 26$ & $y=3.1899 x-0.7226$ & $R^{2}=0.9994$ & $y=4.0603 x+0.9935$ & $\mathrm{R}^{2}=0.9897$ \\
\hline $\mathrm{T} 27$ & $y=3.951 x-1.3582$ & $R^{2}=0.9946$ & $y=3.9499 x+1.2591$ & $\mathrm{R}^{2}=0.9892$ \\
\hline CK & $y=3.5996 x-0.5772$ & $R^{2}=0.9985$ & $y=5.1552 x+1.1224$ & $\mathrm{R}^{2}=0.9932$ \\
\hline
\end{tabular}

\section{References}

1. Al-Omran, A.M.; Mustafa, M.A.; Shalaby, A.A. Intermittent Evaporation from Soil Columns as Affected by a Gel-forming Conditioner. Soil Sci. Soc. Am. J. 1987, 51, 1593-1599. [CrossRef]

2. Ai-Omran, A.M.; Ai-Wabel, M.I.; Shalaby, A.A. Impact of Sewage Sludge on Water Movement in Calcareous Sandy Soils. J. Agric. Mar. Sci. 1997, 2, 59. [CrossRef]

3. Al-Omran, A.M.; Choudhary, M.I.; Shalaby, A.A.; Mursi, M.M. Impact of Natural Clay Deposits on Water Movement in Calcareous Sandy Soil. Arid Land Res. Manag. 2002, 16, 185-193. [CrossRef]

4. Ahmad, M.; Usman, A.R.; Al-Faraj, A.S.; Ahmad, M.; Sallam, A.; Al-Wabel, M.I. Phosphorus-loaded biochar changes soil heavy metals availability and uptake potential of maize (Zea mays L.) plants. Chemosphere 2018, 194, 327-339. [CrossRef]

5. Yang, C.D.; Lu, S.G. Effects of five different biochars on aggregation, water retention and mechanical properties of paddy soil: A field experiment of three-season crops. Soil Tillage Res. 2021, 205, 104798. [CrossRef]

6. Saffari, N.; Hajabbasi, M.A.; Shirani, H.; Mosaddeghi, M.R.; Owens, G. Influence of corn residue biochar on water retention and penetration resistance in a calcareous sandy loam soil. Geoderma 2021, 383, 114734. [CrossRef]

7. Hussain, R.; Ravi, K.; Garg, A. Influence of biochar on the soil water retention characteristics (SWRC): Potential application in geotechnical engineering structures. Soil Tillage Res. 2020, 204, 104713. [CrossRef]

8. Razzaghi, F.; Obour, P.B.; Arthur, E. Does biochar improve soil water retention? A systematic review and meta-analysis. Geoderma 2020, 361, 114055. [CrossRef]

9. Adekiya, A.O.; Agbede, T.M.; Olayanju, A.; Ejue, W.S.; Adekanye, T.A.; Adenusi, T.T.; Ayeni, J.F. Effect of Biochar on Soil Properties, Soil Loss, and Cocoyam Yield on a Tropical Sandy Loam Alfisol. Sci. World J. 2020, 2020, 9391630. [CrossRef] 
10. Verheijen, F.G.; Zhuravel, A.; Silva, F.C.; Amaro, A.; Ben-Hur, M.; Keizer, J.J. The influence of biochar particle size and concentration on bulk density and maximum water holding capacity of sandy vs sandy loam soil in a column experiment. Geoderma 2019, 347, 194-202. [CrossRef]

11. Głąb, T.; Palmowska, J.; Zaleski, T.; Gondek, K. Effect of biochar application on soil hydrological properties and physical quality of sandy soil. Geoderma 2016, 281, 11-20. [CrossRef]

12. Usman, A.R.; Abduljabbar, A.; Vithanage, M.; Ok, Y.S.; Ahmad, M.; Ahmad, M.; Elfaki, J.; Abdulazeem, S.S.; Al-Wabel, M.I. Biochar production from date palm waste: Charring temperature induced changes in composition and surface chemistry. J. Anal. Appl. Pyrolysis 2015, 115, 392-400. [CrossRef]

13. Bridle, T.R.; Pritchard, D. Energy and nutrient recovery from sewage sludge via pyrolysis. Water Sci. Technol. 2004, 50, 169-175. [CrossRef]

14. DeLuca, T.H.; MacKenzie, M.D.; Gundale, M.J. Bio-char effects on soil nutrient transformation. In Biochar for Environmental Management; Lehmann, J., Joseph, S., Eds.; Science and Technology: Earthscan Publications Ltd., London, UK, 2009; pp. 251-270.

15. Ahmad, M.; Ahmad, M.; Usman, A.R.A.; Al-Faraj, A.S.; Abduljabbar, A.; Ok, Y.S.; Al-Wabel, M.I. Date palm waste-derived biochar composites with silica and zeolite: Synthesis, characterization and implication for carbon stability and recalcitrant potential. Environ. Geochem. Health 2019, 41, 1687-1704. [CrossRef]

16. National Center for Palm and Dates (NCPD) 2021; Annual report; Ministry of Environment, Water and Agriculture: Riyadh, Saudi Arabia, 2021.

17. Gee, G.W.; Bauder, J.W. Methods of Soil Analysis: Physical and Mineralogical Methods; Soil Science Society of America and American Society of Agronomy: Madison, WI, USA, 1994; pp. 383-409.

18. Sparks, D.L.; Page, A.L.; Helmke, P.A.; Loeppert, R.H. (Eds.) Methods of Soil Analysis, Part 3: Chemical Methods; John Wiley \& Sons: Hoboken, NJ, USA, 2020; Volume 14.

19. Al-Wabel, M.I.; Al-Omran, A.; El-Naggar, A.H.; Nadeem, M.; Usman, A.R. Pyrolysis temperature induced changes in characteristics and chemical composition of biochar produced from conocarpus wastes. Bioresour. Technol. 2013, 131, 374-379. [CrossRef] [PubMed]

20. Huang, H.; Reddy, N.G.; Huang, X.; Chen, P.; Wang, P.; Zhang, Y.; Huang, Y.; Lin, P.; Garg, A. Effects of pyrolysis temperature, feedstock type and compaction on water retention of biochar amended soil. Sci. Rep. 2021, 11, 1-19. [CrossRef] [PubMed]

21. Mollinedo, J.; Schumacher, T.E.; Chintala, R. Influence of feedstocks and pyrolysis on biochar's capacity to modify soil water retention characteristics. J. Anal. Appl. Pyrolysis 2015, 114, 100-108. [CrossRef]

22. Ippolito, J.A.; Cui, L.; Kammann, C.; Wrage-Mönnig, N.; Estavillo, J.M.; Fuertes-Mendizabal, T.; Borchard, N. Feedstock Choice, Pyrolysis Temperature and Type Influence Biochar Characteristics: A Comprehensive Meta-Data Analysis Review; Springer: Berlin/Heidelberg, Germany, 2020; pp. 1-18.

23. Wang, M.; Zhu, Y.; Cheng, L.; Andserson, B.; Zhao, X.; Wang, D.; Ding, A. Review on utilization of biochar for metal-contaminated soil and sediment remediation. J. Environ. Sci. 2018, 63, 156-173. [CrossRef]

24. Domingues, R.R.; Trugilho, P.F.; Silva, C.A.; De Melo, I.C.N.A.; Melo, L.C.; Magriotis, Z.M.; Sanchez-Monedero, M.A. Properties of biochar derived from wood and high-nutrient biomasses with the aim of agronomic and environmental benefits. PLoS ONE 2017, 12, e0176884. [CrossRef]

25. Park, J.; Hung, I.; Gan, Z.; Rojas, O.; Lim, K.H.; Park, S. Activated carbon from biochar: Influence of its physicochemical properties on the sorption characteristics of phenanthrene. Bioresour. Technol. 2013, 149, 383-389. [CrossRef] [PubMed]

26. Rafiq, M.K.; Bachmann, R.T.; Rafiq, M.T.; Shang, Z.; Joseph, S.; Long, R. Influence of Pyrolysis Temperature on Physico-Chemical Properties of Corn Stover (Zea mays L.) Biochar and Feasibility for Carbon Capture and Energy Balance. PLoS ONE 2016, 11, e0156894. [CrossRef]

27. Murtaza, G.; Ahmed, Z.; Usman, M.; Tariq, W.; Ullah, Z.; Shareef, M.; Iqbal, H.; Waqas, M.; Tariq, A.; Wu, Y.; et al. Biochar induced modifications in soil properties and its impacts on crop growth and production. J. Plant Nutr. 2021, 44, 1-15. [CrossRef]

28. Alkhasha, A.; Al-Omran, A.; Aly, A. Effects of Biochar and Synthetic Polymer on the Hydro-Physical Properties of Sandy Soils. Sustainability 2018, 10, 4642. [CrossRef]

29. Herath, H.; Arbestain, M.C.; Hedley, M. Effect of biochar on soil physical properties in two contrasting soils: An Alfisol and an Andisol. Geoderma 2013, 209-210, 188-197. [CrossRef]

30. Mukherjee, A.; Lal, R. Biochar Impacts on Soil Physical Properties and Greenhouse Gas Emissions. Agronomy 2013, 3, 313-339. [CrossRef]

31. Hussain, R.; Ghosh, K.K.; Ravi, K. Impact of biochar produced from hardwood of mesquite on the hydraulic and physical properties of compacted soils for potential application in engineered structures. Geoderma 2021, 385, 114836. [CrossRef]

32. Gelardi, D.L.; Ainuddin, I.; Rippner, D.A.; Abou Najm, M.; Parikh, S.J. Biochar Alters Hydraulic Conductivity and Inhibits Nutrient Leaching in Two Agricultural Soils; European Geosciences Union: Munich, Germany, 2021; pp. 1-23.

33. Wang, K.; Zhang, X.; Sun, C.; Yang, K.; Zheng, J.; Zhou, J. Biochar application alters soil structure but not soil hydraulic conductivity of an expansive clayey soil under field conditions. J. Soils Sediments 2021, 21, 73-82. [CrossRef]

34. Bai, B.; Long, F.; Rao, D.; Xu, T. The effect of temperature on the seepage transport of suspended particles in a porous medium. Hydrol. Process. 2016, 31, 382-393. [CrossRef]

35. Bai, B.; Nie, Q.; Zhang, Y.; Wang, X.; Hu, W. Cotransport of heavy metals and $\mathrm{SiO}_{2}$ particles at different temperatures by seepage. J. Hydrol. 2021, 597, 125771. [CrossRef] 
36. Liu, Z.; Dugan, B.; Masiello, C.; Barnes, R.T.; Gallagher, M.E.; Gonnermann, H. Impacts of biochar concentration and particle size on hydraulic conductivity and DOC leaching of biochar-sand mixtures. J. Hydrol. 2016, 533, 461-472. [CrossRef]

37. Ibrahim, A.; Usman, A.R.A.; Al-Wabel, M.I.; Nadeem, M.; Ok, Y.S.; Al-Omran, A. Effects of conocarpus biochar on hydraulic properties of calcareous sandy soil: Influence of particle size and application depth. Arch. Agron. Soil Sci. 2016, 63, 185-197. [CrossRef]

38. Alkhasha, A.; Al-Omran, A.; Alghamdi, A.A.G. Effect of Water Quality and Date Palm Biochar on Evaporation and Specific Hydrological Characteristics of Sandy Soil. Agric. 2020, 10, 300. [CrossRef]

39. Ibrahim, H.M.; Al-Wabel, M.I.; Usman, A.R.A.; Al-Omran, A. Effect of Conocarpus Biochar Application on the Hydraulic Properties of a Sandy Loam Soil. Soil Sci. 2013, 178, 165-173. [CrossRef]

40. Alghamdi, A.; Aljohani, B.; Aly, A. Impacts of Olive Waste-Derived Biochar on Hydro-Physical Properties of Sandy Soil. Sustainability 2021, 13, 5493. [CrossRef]

41. Alghamdi, A.G. Biochar as a potential soil additive for improving soil physical properties—A review. Arab. J. Geosci. 2018, 11, 1-16. [CrossRef]

42. Alghamdi, A.G.; Alkhasha, A.; Ibrahim, H.M. Effect of biochar particle size on water retention and availability in a sandy loam soil. J. Saudi Chem. Soc. 2020, 24, 1042-1050. [CrossRef]

43. Eibisch, N.; Durner, W.; Bechtold, M.; Fuß, R.; Mikutta, R.; Woche, S.K.; Helfrich, M. Does water repellency of pyrochars and hydrochars counter their positive effects on soil hydraulic properties? Geoderma 2015, 245-246, 31-39. [CrossRef]

44. Li, W.; Liang, C.; Dong, L.; Zhao, X.; Wu, H. Accumulation and characteristics of fluorescent dissolved organic matter in loess soil-based subsurface wastewater infiltration system with aeration and biochar addition. Environ. Pollut. 2021, 269, 116100. [CrossRef] [PubMed]

45. Duan, M.; Liu, G.; Zhou, B.; Chen, X.; Wang, Q.; Zhu, H.; Li, Z. Effects of modified biochar on water and salt distribution and water-stable macro-aggregates in saline-alkaline soil. J. Soils Sediments 2021, 21, 2192-2202. [CrossRef]

46. Bai, B.; Rao, D.; Chang, T.; Guo, Z. A nonlinear attachment-detachment model with adsorption hysteresis for suspension-colloidal transport in porous media. J. Hydrol. 2019, 578, 124080. [CrossRef] 